\title{
Estudio del efecto de los acabados superficiales en granitos y calizas para su aplicación en pavimentos exteriores de baldosas de piedra
}

\section{The effect of surface finishes on outdoor granite and limestone pavers}

\author{
M.A. García-del-Cura ${ }^{(*, * *)}$, D. Benavente ${ }^{(*, * * *)}$, A. Bernabéu ${ }^{(*, * * *)}$ y J. Martínez-Martínez ${ }^{(*, * *)}$
}

Recepción/Received: 15-VI-07

Aceptación/Accepted: 27-IX-07

Publicado online/Online publishing: 10-XII-07

\section{RESUMEN}

Se han estudiado, para su utilización como baldosas de pavimentos, granito (Blanco Rafaela o Granito de Zarzalejo) y caliza microcristalina (mármol comercial Gris Pulpis) con diferentes acabados. Estos acabados son: pulido, apomazado, abujardado y flameado en ambas rocas y además acabado al ácido y amolado en la caliza.

Se han determinado mediante ensayos estandarizados las tres propiedades físicas de mayor interés para el uso de la piedra natural como baldosa en pavimentos de exteriores: resistencia a la flexión bajo carga concentrada, a la abrasión y al deslizamiento. Se han realizado ensayos de durabilidad por ciclos de hielo-deshielo con posterior evaluación mediante determinación de resistencia a flexión. Se ha estudiado el comportamiento hídrico de los diferentes acabados. Las rocas no ven alterado sustancialmente su comportamiento hídrico por el tipo de acabado.

Palabras clave: baldosas, granito, caliza, acabados superficiales, resistencia a la heladicidad.

\section{SUMMARY}

Two types of ornamental stones, namely granite (Blanco Rafaela or Zarzalejo Granite) and microcrystalline limestone (marble known commercially as Gris Pulpis), treated for different surface finishes, were tested for suitability as paving slabs. The finishes tested in both stones were polishing, hammering, honing and flaming, while acid treatment and abrasion were applied to limestone only and sawn finishes were only studied in granite.

The stones were tested for the three physical properties that determine suitability for use as paving slabs; flexural strength under a concentrated load, and abrasion and slip resistance. Laboratory freeze-thaw cycle ageing tests were also conducted and flexural strength subsequently evaluated. Stone water sorption proved to be substantially unaltered by the type of finish employed.

Keywords: paving slabs, granite, limestone, surface finishes, freeze-thaw resistance.

\footnotetext{
(*) Unidad Asiociada CSIC - Universidad de Alicante (Alicante, España)

(**) Instituto de Geología Económica, CSIC-UCM (Madrid, España)

(***) Universidad de Alicante (Alicante, España).
} 


\section{INTRODUCCIÓN}

Según las estadísticas (1) la producción mundial de piedra natural elaborada es de 56.779 Tm en 2005, dedicándose el $39,7 \%$ a pavimentos. Esta utilización de la piedra natural ha sido la primera en ser normalizada y así en 2002 aparecen las normas europeas de productos correspondientes tanto a baldosas (2) como adoquines y otras piezas de pavimentación. Las propiedades principales para la utilización de piedra natural en baldosas son la resistencia a flexión bajo carga concentrada (3), resistencia al desgaste (abrasión) y al deslizamiento (fricción) tal y como se detalla respectivamente en los anexos $C$ y D de la Norma de Baldosas (2).

Este trabajo se centra en la utilización en baldosas para pavimentaciones de exteriores de granitos y calizas microcristalinas explotadas en España y que han sido utilizadas, tanto en Patrimonio Arquitectónico como en obra nueva y que actualmente están siendo utilizadas para la rehabilitación de cascos históricos.

El trabajo pretende valorar la adecuación de estos materiales para su uso como pavimentos de exteriores y establecer una relación entre las características texturales de los diferentes acabados y las propiedades citadas.

\section{MATERIALES}

\subsection{Granito}

En este trabajo se ha estudiado el granito Blanco Rafaela que se extrae en las proximidades de El Escorial (provincia de Madrid), en la zona de Zarzalejo, por lo que también ha recibido históricamente la denominación de Granito de Zarzalejo (4). Granitos de este tipo han sido empleados entre los siglos XV y XVII en numerosos monumentos de la Comunidad de Madrid. Entre ellos destacan el Real Monasterio de San Lorenzo de El Escorial, el Monasterio de la Encarnación y el Monasterio de las Descalzas Reales, en Madrid. El granito de Zarzalejo ha sido utilizado en intervenciones del siglo XX en el Palacio Real de Madrid (4).

El granito de Zarzalejo pertenece a un batolito hercínico (Carbonífero-Pérmico), de alrededor de $13.000 \mathrm{~km}^{2}$, de composición media monzogranítica emplazado de forma tardia post-orogénica en el Sistema Central de la Península Ibérica (5). Es un granito inequigranular de grano medio a grueso, a veces con textura porfídica (fenocristales de feldespato), ocasionalmente con enclaves microgranulares más básicos. Los componentes mayoritarios de esta roca son plagioclasa (labradorita $\mathrm{Na} \leq \mathrm{Ca}$ ), feldespato potásico (ortoclasa y microclina),

\section{INTRODUCTION}

According to recently published statistics (1), world-wide natural stone production came to 56,779 in 2005, approximately $39.7 \%$ of which was used for paving and flooring. This was the first use of natural stone to be standardized when European rules for paving slabs (2), setts and kerbs came into effect in 2002. The requirements for stone used as outdoor pavers include resistance to flexural strength under a concentrated load (3) and abrasion and slip resistance. The methodology for determining these properties is described in Annexes $C$ and $D$ of the standard on paving slabs (2).

This paper examines the use of granite and microcrystalline limestone slabs as pavers. The stones studied were granite and microcrystalline limestone quarried in Spain, found in both heritage and modern structures and used as well restore historic city centres.

The aim of the present research was to evaluate the suitability of the stone materials studied for use as paving slabs and establish a relationship between the textural characteristics of the different finishes and the aforementioned properties.

\section{MATERIALS}

\subsection{Granite}

Blanco Rafaela granite was used for this study. Quarried at Zarzalejo in the province of Madrid, it also used to be known as Zarzalejo granite (4). This variety of granite was used from the 15th to the 17th centuries in many historic buildings in the region of Madrid, including the Royal Monastery at El Escorial and the La Encarnación and Las Descalzas Royal Monasteries in the capital city. Zarzalejo granite was also used to restore Madrid's Royal Palace in the 20th century (4).

Blanco Rafaela granite from Zarzalejo, part of a batholith measuring approximately $13,000 \mathrm{~km}^{2}$, contains primarily monzogranite formed during the (CarboniferousPermian) Hercynian orogeny in the innermost continental region of the Iberian belt, itself a part of the Spanish Central System (5). It is an inequigranular, fine-to-medium grained granite, sometimes exhibiting a porphyritic texture (feldspar phenocrystals) with an occasional more basic and micro-grained enclaves. The major components are plagioclase (labradorite $\mathrm{Na} \leq \mathrm{Ca}$ ), potassium feldspar (orthoclase 
cuarzo y biotita titanífera (Fe/Ti de 7,8 - a 9,2 y $\approx 0,5 \%$ $\mathrm{Mn})$. Contiene clorita y moscovita como componentes minoritarios. Los minerales accesorios son apatito, monacita, circón e ilmenita, que aparecen principalmente como inclusiones en biotitas (Figura 1A).

Se trata de un granito algo fracturado tal como se observa con microscopio de fluorescencia.

Los acabados estudiados han sido: pulido, apomazado, cara sierra o aserrado (con flejes de acero), abujardado y flameado. El acabado se realiza sólo en la superficie externa de la baldosa. and microcline), quartz and titanium biotite ( $\mathrm{Fe} / \mathrm{Ti}$ from 7.8 to 9.2 and $\approx 0.5 \% \mathrm{Mn}$ ). Its minority components are chlorite and muscovite. The trace minerals, which are mainly present as biotite inclusions, include apatite, monazite, zircon and ilmenite (Figure $1 A$ ).

Under the fluorescent microscope, this granite appeared to be somewhat fractured.

The granite finishes studied were polishing, honing, sawing (with a steel band saw), hammering and flaming. Finishes were applied to the external surface of slabs only.

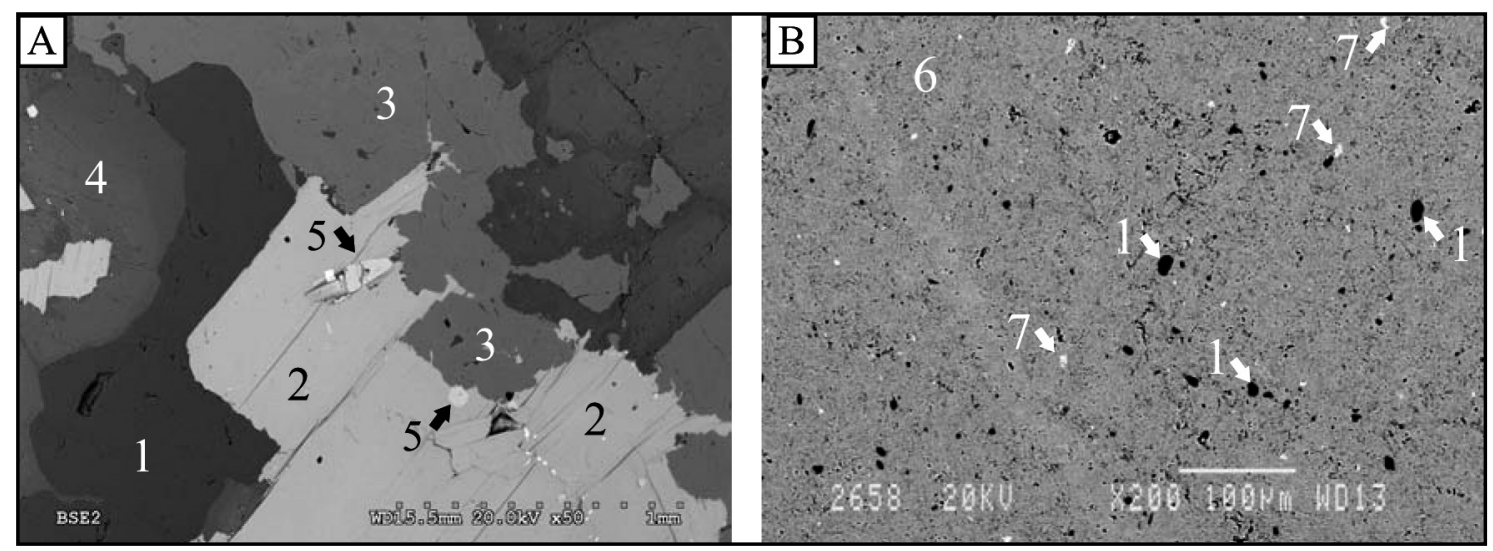

Figura 1. Microfotografías de MEB en modo de electrones retrodispersados:

A ) Granito Blanco Rafaela, B) Caliza Gris Pulpis. 1 Cuarzo, 2 Biotita, 3 feldespato potásico, 4 plagioclasa, 5 apatito, 6 calcita, 7 pirita.

Figure 1. SEM/BSE photomicrographs;

A) Blanco Rafaela Granite B) Gris Pulpis Limestone 1 Quartz, 2 Biotite, 3 Potassium feldspar, 4 plagioclase, 5 apatite, 6 calcite, 7 pyrite.

\subsection{Caliza}

La caliza seleccionada para este trabajo, por su homogeneidad, y variedad de acabados con que se comercializa, ha sido la denominada comercialmente Gris Pulpis, que es una caliza microcristalina del Jurásico de la Cordillera Ibérica (Maestrazgo) (Provincia de Castellón), que por su aptitud para el pulido entra dentro de la categoría de "mármoles comerciales". Es una caliza microcristalina cuyos cristales de calcita varían de 1 a $10 \mu \mathrm{m}$ con indicios de fósiles principalmente planctónicos, contiene cuarzo y pirita como minerales accesorios (Figura 1B). Sus rasgos estructurales más característicos son vénulas de calcita blanca y ocasionalmente estilolitos con rellenos de variada composición mineralógica (fluorita y/o minerales de arcilla y/u óxidos) (6). Esta roca, comercializada principalmente en la última década del siglo $X X$, está siendo muy utilizada en la pavimentación de cascos históricos (Alicante, Elche, Santa Pola, Peñíscola...) y en edificios singulares como el Museo del Prado de Madrid (sala de Goya) y otros (6).

\subsection{Limestone}

The limestone selected for this study is marketed as Gris Pulpis. It was chosen for its homogeneity and the variety of commercial finishes available. This Jurassic microcrystalline limestone from the Maestrazgo region of the Iberian Mountain Range in the Province of Castellón, Spain, is classified as a commercial marble in light of its suitability for polishing. A microcrystalline limestone, its crystals range in size from $1 \mu \mathrm{m}$ to $10 \mu \mathrm{m}$. It contains plankton fossils, quartz and pyrite as trace minerals (Figure 1B) (6). Structurally, it exhibits white calcite veins having occasional stylolites filled with different minerals (fluorite and/or clay minerals and/or oxides). This stone was mainly marketed in the 1990's, this stone is currently being used to pave the historic centres of cities such as Alicante, Elche, Santa Pola and Peñíscola, as well as for flooring in such emblematic buildings as Madrid's Prado Museum, specifically in the Goya rooms (6). 
Los acabados estudiados han sido: pulido, apomazado, al ácido (matizado), amolado, abujardado y flameado. Estos acabados condicionan las propiedades estéticas de las baldosas (color y brillo), y la rugosidad de la superficie. La rugosidad es mayor en los acabados flameado y abujardado y es mínima en el acabado pulido. El acabado se realiza sólo en la superficie externa de la baldosa. No se comercializa el acabado aserrado por sus malas características cromáticas. El acabado amolado es el más próximo al aserrado por sus características físicas, ya que su realización sólo implica un ligero tratamiento con abrasivo para que no sean visibles las líneas de corte. La superficie de la roca en afloramiento aparece colonizada y/o decolorada (6).

Según el estudio colorimétrico previo realizado en la caliza Gris Pulpis (6) los acabados pulido, apomazado y al ácido aumentan los valores de cromaticidad (mayores valores de C que "avivan" los colores), en especial el acabado pulido, en relación con una disminución de la rugosidad (7), mientras que los acabados flameado, abujardado y amolado aumentan la luminosidad (aumentan los valores de $\mathrm{L}$, dando tonos más claros). Las características colorimétricas del acabado apomazado coinciden con las de la roca en fractura fresca.

\section{METODOLOGÍA}

Las características texturales y mineralógicas de los materiales pétreos estudiados han sido determinadas mediante microscopía óptica de luz transmitida (secciones delgadas y microscopio Zeiss, Assioscop) y microscopia electrónica de barrido (MEB) en modo de electrones retrodispersados. Se ha utilizado un microscopio de presión variable Hitachi S-3000N con un detector de rayos X tipo XFlash 3001 de Bruker para microanálisis (EDS), trabajando sobre secciones pulidas, primero sin recubrir (bajo vacío) y posteriormente recubiertas con carbono (alto vacío) . La textura de los acabados ha sido estudiada con MEB en modo de electrones secundarios, trabajando a $20 \mathrm{Kv}$, con el microscopio citado y recubrimiento previo con oro. Se han estudiado secciones delgadas de granitos impregnadas con fluoresceína con el microscopio de fluorescencia.

Para hacer la caracterización petrofísica de los dos tipos de roca se ha estudiado su sistema poroso, sus propiedades elásticas dinámicas (mediante ultrasonidos) y su isotropía.

La porosidad total ha sido caracterizada mediante el procedimiento de la norma UNE-EN 1936 (8) para la determinación de la densidad aparente $\left(\rho_{a p}\right)$ y picnometría de helio (empleándose un picnómetro AccuPyc 1330) para la determinación de la densidad real $\left(\rho_{\text {real }}\right)$. La porosidad total ha sido calculada utilizando los datos de ambas densidades (8) según la siguiente ecuación [1]:
The following limestone finishes were studied: polishing, honing, acid treatment, abrasion, hammering and flaming. These finishes determine slab aesthetics in terms of colour and brightness, as well as surface roughness. The roughest surfaces are obtained with hammering and flaming, and the smoothest with polishing. The finishes were applied to the external surface of slabs only. Marble with a sawn finish is not marketed because of its poor colouring. The finish that resembles sawing most closely is abrasion, which involves little more than slight sanding to smooth the saw marks. In outcrops, limestone surfaces are always colonized by lichens and/or have faded colours (6).

A previous colorimetric study conducted on Gris Pulpis (6) showed that particularly polishing, but also honing and acid-treatment, enhanced the chromaticity $(C)$ or hue and saturation values. This effect is the result of reducing surface roughness (7), whilst flaming, hammering and abrasion increase luminosity ( $L$ ). In honed finishes, the colorimetric traits are the same as in broken stone.

\section{METHODOLOGY}

Thin sections were examined under an Assioscop Zeiss transmitted light microscope and with back scattered electron microscopy to determine the textural and mineralogical characteristics of the stone materials. A Hitachi S-3000N low voltage imager fitted with a Bruker XFlash $3001 X$ ray detector was used for EDS microanalysis to analyze both (low vacuum) uncoated polished surfaces and (high vacuum) carbon-coated surfaces. Finish texture was studied with gold-coated samples using secondary electron SEM at an accelerating voltage of $20 \mathrm{kV}$. Fluorescence microscopy was employed to examine thin sections of fluoresceine-impregnated granite.

Stone porous systems, elastic dynamic properties and anisotropy were studied to determine their petrophysical characterization.

Total porosity was found as specified in Spanish/ European standard UNE-EN 1936 (8) to determine apparent density $\left(\rho_{a p}\right)$. Real density $\left(\rho_{\text {real }}\right)$ was obtained with an AccuPyc helium pycnometer and total porosity was calculated from these two values as follows [1]: 


$$
P_{T}(\%)=\left(1-\frac{\rho_{a p}}{\rho_{\text {real }}}\right) \cdot 100
$$

Las velocidades ultrasónicas han sido medidas mediante el método de transmisión-recepción directo con un equipo Sonic Viewer 170 OYO, Mod. 5228, usando transductores polarizados Panametric (1 MHz). Se ha seleccionado una frecuencia mayor que la aconsejada en la norma UNE-EN 14579 (20-150 kHz) (9) para poder obtener una mayor interacción (mayor resolución) entre las ondas mecánicas y los elementos texturales de las rocas. La velocidad de las ondas $\mathrm{P}\left(\mathrm{v}_{\mathrm{p}}\right)$ y $\mathrm{S}\left(\mathrm{v}_{\mathrm{s}}\right)$ se ha calculado a partir del cociente entre la longitud de la probeta y el tiempo de vuelo del pulso. Para cada determinación se han utilizado tres probetas secas de geometría cúbica $(7 \mathrm{~cm})$.

Con el fin de obtener un óptimo acoplamiento entre el transductor y la muestra, se ha empleado un gel viscoelástico (Eco-gel) para la medida de las velocidades de las ondas $\mathrm{P}$ mientras que para las $\mathrm{v}_{\mathrm{s}}$ se ha utilizado un acoplador de incidencia normal (SWC, shear wave couplant, GE Panametrics ${ }^{\circledR}$ ). En cada probeta se han realizado medidas en tres direcciones ortogonales. La anisotropía de las muestras se ha calculado mediante el coeficiente de anisotropía (A). Este coeficiente se ha obtenido a partir del cociente entre el valor mínimo y el valor máximo registrado en cada probeta (10). Este valor (parámetro A) puede oscilar entre 0 y 1 . Si el cociente es igual a 1 , la muestra puede ser considerada perfectamente isótropa, mientras que conforme el valor desciende de 1 , la anisotropía de la muestra aumenta. Cuando el valor del coeficiente es próximo a 0 , la muestra posee una elevada anisotropía $(10,11)$.

En función de las prestaciones que las rocas deben tener para su uso como pavimentos (12) se ha determinado la cinética de absorción y de desorción de agua. La cinética de absorción capilar se ha realizado para los diferentes acabados siguiendo la metodología indicada en la norma UNE-EN 1925 (13). Se han utilizado tres probetas con geometría prismática de $2,5 \times 2,5 \times 4,0 \mathrm{~cm}$ de cada tipo y agua destilada. Las curvas de capilaridad se han obtenido representando la masa de agua absorbida por unidad de superficie frente a la raíz cuadrada del tiempo. La primera parte de la curva corresponde a la absorción de agua y su pendiente se define como coeficiente de absorción capilar, mientras la segunda parte corresponde a la saturación.

La desorción de agua se ha determinado sobre probetas

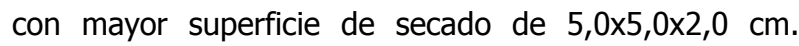
Dichas probetas fueron saturadas durante 48 horas en agua. La desorción o secado de las probetas se realizó a $20{ }^{\circ} \mathrm{C}$ y $60 \%$ de humedad relativa. Los laterales de las muestras se sellaron con parafina para favorecer que la
An OYO 170 mod. 5228 Sonic Viewer was employed to measure ultrasonic velocity with $1-\mathrm{MHz}$ polarized Panametric transducers. The frequency used was higher than the 20-150 kHz recommended in Spanish-European standard 14579 (9) to enhance the interaction between the mechanical waves and the textural elements of the stone (and heighten resolution). Compression $\left(v_{p}\right)$ and shear $\left(v_{s}\right)$ wave velocities were determined from the ratio of the specimen length to pulse transit time. Three dry cubic $(7-\mathrm{cm})$ specimens were used for each measurement.

The P-wave signal was recorded with an ultrasound ecogel, using a viscous-elastic couplant to ensure optimal contact between the transducer and the sample, while the S-wave signal was enhanced using a GE Panametrics ${ }^{\circledR}$ shear wave couplant (SWC) for normal incidence transducers. Samples were measured in the three perpendicular directions. The ratio between the minimum and maximum values was calculated to obtain sample anisotropy (10). The result is a value between zero and one. A ratio of one means that the sample is perfectly isotropic for the attribute considered, with anisotropy increasing as the value declines. A coefficient of close to zero is indicative of very high anisotropy $(10,11)$.

Capillary water absorption and evaporation kinetics were obtained to verify whether the stones met the requisites laid down for pavers (12). Capillary absorption was tested to Spanish/European standard UNE-EN 1925 (13), using $2.5 \times 2.5 \times 4 \mathrm{~cm}$ prisms and distilled water. The results were plotted as the mass of water absorbed per area of sample during imbibition, versus the square root of time. The first leg of the curve defines water adsorption, in which the slope represents the water absorption coefficient; the second leg denotes rock saturation.

The evaporation test was conducted on prisms with a larger evaporation surface, measuring $5.0 \times 5.0 \times 2.0 \mathrm{~cm}$. Samples were saturated in distilled water for 48 hours and then dried at a temperature of $20^{\circ} \mathrm{C}$ and a relative humidity of $60 \%$. The edges of the specimens were sealed with paraffin to favour evaporation through the treated side. 
evaporación se produjera en la cara del acabado. Las curvas de secado se han obtenido representando la pérdida de agua en función de la raíz cuadrada del tiempo.

Las propiedades mecánicas que se han determinado son las que se incluyen en los métodos de ensayo de piedra natural para su uso como baldosas en pavimento exterior (2): resistencia a flexión bajo carga concentrada (3), resistencia al desgaste o abrasión y resistencia al deslizamiento (Anexos C y $\mathrm{D}$ respectivamente de la norma de baldosas).

En primer lugar se ha obtenido el valor de la resistencia a flexión bajo carga concentrada (3). Previamente a la realización del ensayo las probetas se han secado y se ha empleado una velocidad de carga de 0,004 kn/s. Para la realización del ensayo la cara del acabado se sitúa en contacto con el apoyo inferior. Se ha utilizado una prensa de rotura Ibertest Modelo MEH-200H /FIB-50.

Para la determinación de la resistencia al desgaste (2) se mide la anchura de la huella $(\mathrm{mm})$ producida en la superficie del acabado estudiado sometido al rozamiento de un disco de acero y un material abrasivo bajo condiciones normalizadas, utilizando un equipo Ibertest DIB-70. Los mayores valores de resistencia corresponden a las dimensiones menores de la huella.

La resistencia al deslizamiento (2), especialmente importante en pavimentos de áreas peatonales, se ha obtenido empleando un péndulo TRRL-Wessex provisto de una zapata de goma, que se deja caer sobre la probeta a ensayar, determinándose mediante una escala graduada, que va de cero a 100, la fricción producida sobre la probeta. El valor de esta escala se expresa como USRV (Unpolished Slip Resistance Value: valor de la resistencia al deslizamiento de la superficie sin pulido). Los valores han sido obtenidos según se detalla en el anexo D de la norma UNE-EN 1341 (2), determinándose en todos los casos el valor de la resistencia del material sobre superficies saturadas en agua.

Para la evaluación de la durabilidad de las rocas estudiadas se ha determinado la resistencia a los ciclos de hielodeshielo. El ensayo se ha llevado a cabo mediante la realización de 25 ciclos de 24 horas de saturación en agua y posterior congelación con una variación de temperatura en el rango de $-15{ }^{\circ} \mathrm{C}$ y $20{ }^{\circ} \mathrm{C}$. Para evaluar este ensayo se ha determinado la variación de la resistencia a flexión bajo carga concentrada, comparando el valor de dicha propiedad con el obtenido sobre las probetas sometidas a los ciclos de hielo - deshielo (ensayo tecnológico) (14).

\section{RESULTADOS Y DISCUSION}

Los granitos y las calizas microcristalinas estudiados se pueden considerar prácticamente isótropos, según los
The drying curves were plotted as water loss per evaporation area versus square root of time.

The standard mechanical properties tested were the ones required for stone used as outdoor pavers(2), namely flexural strength under a concentrated load (3) and abrasion and slip resistance (Annexes $C$ and $D$, respectively, of the standard on paving slabs).

Flexural strength under a concentrated load was determined for all the samples. Prior to testing, the specimens were dried. A load rate of $0.004 \mathrm{kn} / \mathrm{s}$ was used, with the finished face down (3). An Ibertest MEH-200H /FIB-50 testing machine was used.

Abrasion resistance was determined (2) by measuring the width of the impression $(\mathrm{mm})$ left by abrasive material applied to the test surface with a steel disc under standard experimental conditions. The smaller the dimensions of the impression, the higher the resistance. Ibertest DIB-70 equipment was used.

Slip resistance values (2) were obtained with a TRRLWessex pendulum, consisting of an adjustable pendulum with a rubber shoe at one end. As this pendulum was slid over the surface of the tested stone, the friction generated was measured on a graduated scale with values ranging from 0 to 100, expressed in unpolished slip resistance values or USRV (Unpolished Slip Resistance Value). These values were determined on specimens with watersaturated surfaces, as specified in Annex $D$ to Spanish and European standard UNE-EN 1341 (2).

Freeze-thaw resistance was established to determine stone durability (5). The test consisted in twenty five 24hour cycles, with temperatures ranging from $-15^{\circ} \mathrm{C}$ to $20{ }^{\circ} \mathrm{C}$. Samples were water-saturated and then exposed to freezing temperatures in each cycle to evaluate frost resistance. The variation in flexural strength under a concentrated load was subsequently determined by comparing values obtained before and after the freeze - thaw cycles (14).

\section{RESULTS AND DISCUSSION}

According to the ultrasound data for granite and microcrystalline limestone, both materials studied were 
datos del estudio con ultrasonidos, ya que ambos materiales presentan valores del coeficiente de anisotropía (A) muy elevados (próximos a 1), (Tabla 1). Este hecho contribuye a la homogeneidad de las baldosas manufacturadas. nearly isotropic, with anisotropic coefficient values $(A)$ of close to one (Table 1). These findings substantiate the homogeneity of the market product.

Tabla 1 / Table 1

Valores medios y desviaciones estándares de $v_{p}, v_{s}$ y coeficiente de anisotropía (A). Mean values and standard deviations of $v_{p}, v_{s}$ and anisotropic coefficient $(A)$.

\begin{tabular}{|l|c|c|c|c|}
\cline { 2 - 4 } \multicolumn{1}{c|}{} & $\mathbf{v}_{\mathbf{p}}$ & $\mathbf{v}_{\mathbf{s}}$ & \multirow{2}{*}{$\mathbf{v}_{\mathbf{p}} / \mathbf{v}_{\mathbf{s}}$} & A \\
\cline { 2 - 5 } \multicolumn{1}{c|}{$[\mathbf{m} / \mathbf{s}]$} & {$[\mathbf{m} / \mathbf{s}]$} & $1.9 \pm 0.0$ & $0.99 \pm 0.01$ \\
\hline $\begin{array}{l}\text { Caliza Gris Pulpis } \\
\text { Gris Pulpis Limestone }\end{array}$ & $6017.3 \pm 61.8$ & $3190.4 \pm 26.5$ & $1.6 \pm 0.1$ & $0.91 \pm 0.04$ \\
\hline $\begin{array}{l}\text { Granito Blanco Rafaela } \\
\text { Blanco Rafaela Granite }\end{array}$ & $4258.2 \pm 266.3$ & $2664.4 \pm 101.0$ & \\
\hline
\end{tabular}

Los procesos físicos de los acabados afectan diferencialmente a granitos y calizas, así el acabado flameado en granitos hace que los minerales más refractarios (ej., micas) aparezcan con relieve positivo en la superficie del acabado (Figura 2A). Un efecto similar se ha visto en otros granitos (15). El acabado flameado crea pequeñas esferas de fusión con los minerales accesorios en el Gris Pulpis y contribuye a fisurar los cristales de calcita (Figura 3A). El acabado abujardado puede hacer un efecto de "apertura" de los agregados micáceos en el granito (Figura 2B) y en las calizas acentúa en superficie las discontinuidades. Esto es muy visible en el caso de los estiIolitos, ya que dichas discontinuidades "favorecen" la alteración debida al proceso de abujardado (Figura 3B). Un efecto parecido tiene el amolado en las calizas. El acabado aserrado en granito crea superficies parecidas a las correspondientes de fractura fresca y el pulido cierra parcialmente la porosidad superficial al depositar en los poros
The physical processes initiated by the type of finish applied were found to affect granite and limestone in different ways. In granite specimens, for instance, flaming caused most of the refractory minerals (e.g., micas) to stand out in relief on the surface (Figure 2A). Similar findings have been reported for other types of granite (15). By contrast, in Gris Pulpis limestone flaming caused the accessory minerals to merge into spherical formations and contributed to calcite crystal fissuring (Figure 3A). Hammering may lead to the disaggregation of mica clusters in granite (Figure $2 B$ ) and to greater surface discontinuities in limestone. This was clearly visible in the case of stylolites, which were altered in hammered finishes (Figure 3B). Similar effects were observed in abraded limestone. Sawn granite surfaces resembled broken natural surfaces, while polishing reduced porosity, for the tiny particles generated clogged the pores. Honed finishes exhibited characteristics mid-way between polished

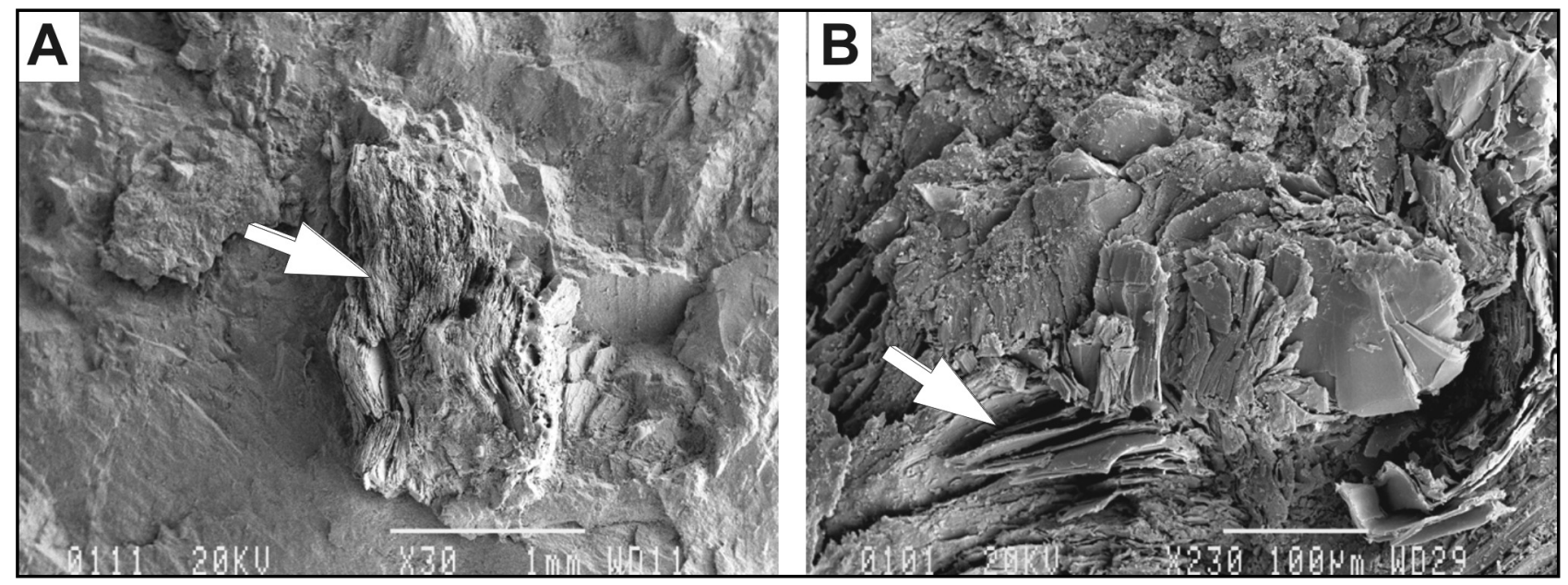

Figura 2. Microfotografías de MEB en modo de electrones secundarios de superficies con diferentes acabados del granito Blanco Rafaela: A) Flameado. B) Abujardado.

Figure 2. SEM/BSE se photomicrographs of surfaces with different finishes of Blanco Rafaela granite; A) Flamed. B) Hammered. 
pequeñas partículas originadas por el proceso de pulido. El acabado apomazado presenta rasgos intermedios entre el pulido y el aserrado, dando a las calizas un acabado con pequeños relieves, correspondientes a zonas con mayor tamaño de cristal más resistentes al proceso de acabado (Figura 3C). Características similares confiere el acabado amolado. El acabado al ácido, específico de las calizas, crea formas de disolución en los cristales mayores (Figura 3D) y relieves positivos en zonas de menor alterabilidad.

En casos de calizas composicionalmente homogéneas como el Gris Pulpis las vénulas rellenas de calcita de mayor tamaño de cristal, presentan relieve positivo respecto al resto de la roca de menor tamaño de cristal. Este hecho se produce por la disolución preferencial de los cristales de calcita de tamaño micrométrico, debido al exceso de energía superficial que crea la interfase sólidodisolución. Esto hace que, en general, el acabado al ácido tenga mayor resistencia al deslizamiento que los acabados pulido y apomazado.

El tipo de acabado afecta poco a la resistencia a flexión del granito (Tabla 2) e introduce ligeramente más variaciones en la resistencia a flexión de las calizas (Tabla 3). Así el acabado flameado presenta unos valores de resistencia menores en las calizas mientras que no afecta a la resistencia de los granitos. La presencia de minerales más sensibles a las altas temperaturas en una roca sedimentaria explicaría este comportamiento diferencial.

En todo caso los valores menores de resistencia a flexión pueden compensarse con un aumento de grosor de las baldosas a utilizar (2), ya que el parámetro que se considera a la hora de diseñar un pavimento es la "carga de rotura", P (kN), la cual se calcula según la ecuación [2]:

$$
P=\frac{R_{f} \cdot W \cdot t^{2}}{1500 \cdot L \cdot 1,6}
$$

donde $t(\mathrm{~mm}), W(\mathrm{~mm})$ y $L(\mathrm{~mm})$, son respectivamente el espesor, la anchura y la longitud de la baldosa; $R_{f}$ (MPa) es la resistencia a flexión bajo carga concentrada y 1,6 es el factor de seguridad recomendado.

En las Tablas 2 y 3 se han incluido los valores de carga de rotura para los diferentes acabados, considerando una baldosa comercial cuyas dimensiones son 300 x $600 \mathrm{~mm}$. Recordemos que la carga de rotura mínima aconsejada para áreas peatonales es 3,5 kN y para vehículos ligeros y accesos ocasionales de coches 6,0 kN (2). En general las calizas no sólo presentan menores valores de resistencia a flexión sino que las desviaciones standard de los valores de dicho parámetro también son mayores (Tabla 3) debido a la existencia de heterogeneidades estructurales: cuando están presentes estilolitos y vénulas las pro- and sawn treatments, generating protrusions in areas containing larger crystals that tend to be more resistant to this finishing process (Figure 3C). Similar findings were observed in the abraded specimens. By dissolving the larger crystals (Figure 3D), acid treatment, which was applied to limestone only, generated protrusions in the least altered areas.

In homogeneous limestone such as Gris Pulpis, the large calcite crystals in the veins stand out in relief against the rest of the stone, where the crystals are smaller. This is the result of the differential dissolution of micrometric calcite crystals stemming from the excess surface energy generated at the solution-solid interface. This finding explains the enhanced slip resistance in acid-treated limestone.

Finish type was found to have no effect on flexural strength in granite (Table 2) and only a minor impact on limestone (Table 3). Limestone flexural strength was lowest when flamed, although this technique had no effect on granite strength. The difference in behaviour in the two stones may be due to the existence in the former of minerals that are particularly sensitive to high temperatures.

Low flexural strength can be offset by increasing paver thickness (2), inasmuch as the parameter governing pavement design is ultimate load $(P)(k N)$ [2]:- where $t(\mathrm{~mm}), W(\mathrm{~mm})$, and $L(\mathrm{~mm})$, are the depth, width and length of the paver respectively, $R_{f}(\mathrm{MPa})$ is the flexural strength under concentrated load and 1.6 is the recommended safety factor.

The standard specimen size for obtaining this value is a $300 \times 600 \mathrm{~mm}$ commercial paver. The ultimate load values for the various finishes are shown in Tables 2 and 3. The minimum ultimate load value recommended for pedestrian use is $3.5 \mathrm{kN}$, while the recommendation for light and occasional standard vehicle access is $6.0 \mathrm{kN}$ (2). Generally speaking, limestone showed not only lower flexural strength, but higher standard deviation values (Table 3) than granite, due to structural heterogeneities. In the presence of veins and stylolites, the samples ten- 

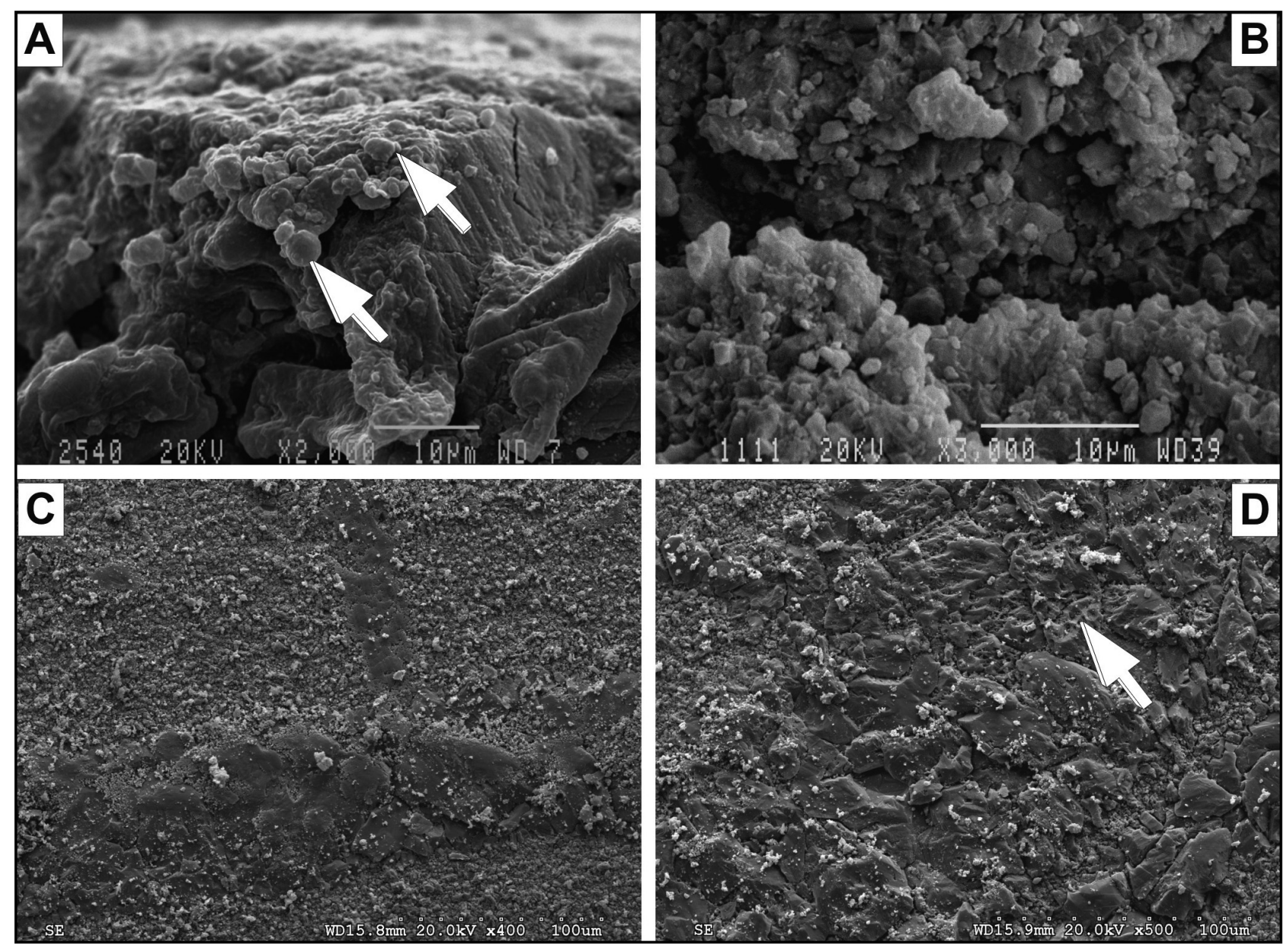

Figura 3.- Microfotografías de MEB en modo de electrones secundarios de superficies con diferentes acabados de la caliza Gris Pulpis: A) Flameado, B) Abujardado, C) Apomazado, D) Al ácido

Figure 3. SEM/BSE se photomicrographs of surfaces with different finishes of Gris Pulpis limestone; A) Flamed, B) Hammered, C) Honed, D) Acid treated.

betas se rompen por dichas superficies con valores menores de resistencia.

La resistencia a la abrasión o desgaste es menor en las calizas, variando poco con el tipo de acabado $(\approx 20 \mathrm{~mm}$ ) (Tabla 3). En el granito los valores más altos de resistencia al desgaste corresponden al acabado pulido $(\approx 12$ $\mathrm{mm}$ ) (Tabla 2). El valor aconsejado de esta propiedad para prestaciones medias es $23 \mathrm{~mm}$ y para altas prestaciones $18 \mathrm{~mm}$ (17).

La resistencia al deslizamiento es uno de los parámetros de mayor importancia para el estudio de la adecuación de una roca con un acabado superficial concreto para su uso en pavimentos, en especial cuando se trata de una obra pública. El tipo de acabado ejerce una gran influencia en la resistencia al deslizamiento, ya que de él depende la rugosidad de la superficie, siendo el acabado abujardado el que presenta valores más favorables en ambos tipos de rocas (Tablas 2 y 3). El acabado flameado en granito presenta también muy buenos valores de resistencia al des- ded to break along the surfaces having lower flexural strength values.

Abrasion resistance, which is generally lower in limestone, varied very little with the different types of finish ( $\approx 20 \mathrm{~mm}$ ) (Table 3). Polishing afforded the highest abrasion resistance in granite $(\approx 12 \mathrm{~mm}$ ) (Table 2$)$. The recommended value for this property is $23 \mathrm{~mm}$ for standard and $18 \mathrm{~mm}$ for high performance (17).

Slip resistance is one of the most important parameters to be considered when determining the suitability of a paving stone or tile surface finish, particularly in public works intended for pedestrian traffic. Finish has a substantial impact on slip resistance inasmuch as it determines surface roughness. Hammering yielded the best results in both types of stone (Tables 2 and 3). Flaming also afforded high slip resistance values (Table 2). The lower slip resistance values recorded for polished stone render it inappropriate for outdoor stone paving. Polished 
Tabla 2 / Table 2

Propiedades mecánicas de las baldosas del Granito Blanco Rafaela.

Standard mechanical properties of Blanco Rafaela granite slabs.

\begin{tabular}{|c|c|c|c|c|c|c|}
\hline \multirow{2}{*}{\multicolumn{2}{|c|}{$\begin{array}{l}\text { Propiedad } \\
\text { Property }\end{array}$}} & \multicolumn{5}{|c|}{$\begin{array}{c}\text { Tipo de Acabado } \\
\text { Type of finish }\end{array}$} \\
\hline & & $\begin{array}{l}\text { Pulido } \\
\text { Polished }\end{array}$ & $\begin{array}{l}\text { Apomazado } \\
\text { Honed }\end{array}$ & $\begin{array}{l}\text { Cara sierra } \\
\text { Sawn }\end{array}$ & $\begin{array}{l}\text { Abujardado } \\
\text { Hammered }\end{array}$ & $\begin{array}{l}\text { Flameado } \\
\text { Flamed }\end{array}$ \\
\hline \multicolumn{2}{|c|}{$\begin{array}{l}\text { Resistencia a flexión bajo } \\
\text { carga concentrada } \\
\text { Flexural strength under } \\
\text { concentrated load (MPa) (3) }\end{array}$} & $17.9 \pm 0.6$ & $14.2 \pm 1.2$ & $15.5 \pm 1.1$ & $16.5 \pm 0.6$ & $15.1 \pm 0.9$ \\
\hline \multicolumn{2}{|c|}{$\begin{array}{l}\text { Carga rotura baldosa } \\
\text { Load of rupture } \\
(600 \times 300 \mathrm{~mm})(\mathrm{kN})(2)\end{array}$} & & & & & \\
\hline $\begin{array}{l}\text { Espesor } \\
\text { Thickness }\end{array}$ & $\begin{array}{l}2 \mathrm{~cm} \\
3 \mathrm{~cm} \\
4 \mathrm{~cm}\end{array}$ & $\begin{array}{l}1.5 \\
3.4 \\
6.0\end{array}$ & $\begin{array}{l}1.2 \\
2.7 \\
4.7\end{array}$ & $\begin{array}{l}1.3 \\
2.9 \\
5.2\end{array}$ & $\begin{array}{l}1.4 \\
3.1 \\
5.5\end{array}$ & $\begin{array}{l}1.3 \\
2.8 \\
5.0\end{array}$ \\
\hline \multicolumn{2}{|c|}{$\begin{array}{l}\text { Resistencia desgaste } \\
\text { Abrasión resistance (mm) (2) }\end{array}$} & $12.5 \pm 0.1$ & $15.5 \pm 0.1$ & $14.0 \pm 2.5$ & $14.5 \pm 0.5$ & --- $(*)$ \\
\hline \multicolumn{2}{|c|}{$\begin{array}{l}\text { R. deslizamiento } \\
\text { Slip resistance } \\
\text { (USRV) (2) }\end{array}$} & $20 \pm 0.1$ & $60 \pm 0.1$ & $72 \pm 2.3$ & $81 \pm 0.4$ & $83 \pm 0.4$ \\
\hline \multicolumn{2}{|c|}{$\begin{array}{l}\text { Flexural strength under } \\
\text { concentrated load after } \\
\text { freeze - thaw cycles } \\
(\mathrm{MPa})(13)\end{array}$} & $18.0 \pm 0.2$ & $14.3 \pm 1.4$ & $15.3 \pm 1.1$ & $16.8 \pm 0.7$ & $13.2 \pm 1.6$ \\
\hline
\end{tabular}

(*) Dada la irregularidad de la superficie no se pueden obtener datos significativos, si bien serían del orden de $10 \mathrm{~mm}$ (datos no normativos).

(*) Non-significant data because the irregularity of surface. Data around $10 \mathrm{~mm}$ (non normative data).

lizamiento (Tabla 2). El acabado pulido presenta los valores menores de resistencia al deslizamiento, siendo este acabado totalmente desaconsejable para pavimentos de exteriores (siempre que no se añada ningún elemento de seguridad adicional) y en especial en el caso de las calizas. El valor de la escala de medida va de cero a 100 , siendo próxima a cero en el caso de una superficie de muy baja resistencia al deslizamiento (por ejemplo para superficies pulidas es habitual valores en torno a 10 en esta escala), correspondiendo los mayores valores a las superficies de mayor rugosidad (valores del orden de 70). Valores de este parámetro inferiores a 35 USRV son desaconsejables para su utilización en pavimentos de exteriores. Los requerimientos respecto de este parámetro son: USRV $\geq 35$ y USRV $\geq 45$ para altas prestaciones (ej. pavimentos en rampa) (17).

En cuanto a los ensayos de durabilidad de las rocas estudiadas por ciclos hielo - deshielo, los ciclos a los que han sido sometidas las probetas, no han afectado de modo limestone would therefore be the stone least suitable for such use. Slip resistance is measured on a scale of 0 to 100 , with zero denoting very low resistance and the highest values (around 70) corresponding to very rough surfaces. The value recorded for polished surfaces, for instance, was 10. Materials with values under 35 USRV should not be used for outdoor paving. Standard performance for this parameter is regarded to be USRV $\geq 35$ and high performance (as needed on paved ramps and slopes, for instance) is USRV $\geq 45$ (17).

Freeze-thaw cycles have been shown to alter paver surfaces only slightly and to have no effect at all on the flexural strength of granite (Table 2). In limestone, in turn, 
apreciable a la resistencia a flexión del granito (Tabla 2), mientras que en la caliza estudiada el acabado pulido es el que menos se ha visto afectado en su resistencia a flexión por este ensayo (Tabla 3). flexural strength was found to be highest in polished specimens (Table 3).

Tabla 3 / Table 3

Propiedades mecánicas de las baldosas de la Caliza Gris Pulpis.

Standard mechanical properties of Gris Pulpis limestone slabs.

\begin{tabular}{|c|c|c|c|c|c|c|c|}
\hline \multirow{2}{*}{\multicolumn{2}{|c|}{$\begin{array}{l}\text { Propiedad } \\
\text { Property }\end{array}$}} & \multicolumn{6}{|c|}{$\begin{array}{c}\text { Tipo de Acabado } \\
\text { Type of finish }\end{array}$} \\
\hline & & $\begin{array}{c}\text { Pulido } \\
\text { Polished }\end{array}$ & $\begin{array}{c}\text { Flameado } \\
\text { Flamed }\end{array}$ & $\begin{array}{c}\text { Al ácido } \\
\text { Acid treated }\end{array}$ & $\begin{array}{c}\text { Apomazado } \\
\text { Honed } \\
\end{array}$ & $\begin{array}{c}\text { Abujardado } \\
\text { Hammered }\end{array}$ & $\begin{array}{l}\text { Amolado } \\
\text { Abrasion } \\
\end{array}$ \\
\hline \multicolumn{2}{|c|}{$\begin{array}{l}\text { Resistencia a flexión bajo } \\
\text { carga concentrada } \\
\text { Flexural strength under } \\
\text { concentrated load( } \mathrm{MPa})(3)\end{array}$} & $14.2 \pm 2.4$ & $8.6 \pm 2.4$ & $14.5 \pm 0.8$ & $10.7 \pm 1.9$ & $14.6 \pm 2.1$ & $12.7 \pm 2.2$ \\
\hline \multicolumn{2}{|c|}{$\begin{array}{l}\text { Carga rotura baldosa } \\
\text { Load of rupture } \\
(600 \times 300 \mathrm{~mm} .)(\mathrm{kN})(2)\end{array}$} & & & & & & \\
\hline Espesor: & $\begin{array}{l}2 \mathrm{~cm} \\
3 \mathrm{~cm} \\
4 \mathrm{~cm}\end{array}$ & $\begin{array}{l}1.2 \\
2.7 \\
4.7\end{array}$ & $\begin{array}{l}0.7 \\
1.6 \\
2.9\end{array}$ & $\begin{array}{l}1.2 \\
2.7 \\
4.8\end{array}$ & $\begin{array}{l}0.9 \\
2.0 \\
3.6\end{array}$ & $\begin{array}{l}1.2 \\
2.7 \\
4.9\end{array}$ & $\begin{array}{l}1.1 \\
2.4 \\
4.2\end{array}$ \\
\hline \multicolumn{2}{|c|}{$\begin{array}{l}\text { Resistencia desgaste } \\
\text { Abrasion resistance } \\
(\mathrm{mm})(2)\end{array}$} & $19.5 \pm 0.1$ & $19.0 \pm 0.5$ & $20.0 \pm 0.1$ & $19.0 \pm 0.1$ & $18.5 \pm 0.5$ & $19.0 \pm 0.2$ \\
\hline \multicolumn{2}{|c|}{$\begin{array}{l}\text { Resistencia al deslizamiento. } \\
\text { Slip resistance } \\
\text { USRV (2) }\end{array}$} & $10 \pm 1$ & $46 \pm 1$ & $17 \pm 1$ & $14 \pm 1$ & $84 \pm 2$ & $50 \pm 1$ \\
\hline \multicolumn{2}{|c|}{$\begin{array}{l}\text { R. flexión bajo carga } \\
\text { concentrada después de } \\
\text { ciclos de hielo-deshielo }\end{array}$} & & & & & & \\
\hline \multicolumn{2}{|c|}{$\begin{array}{l}\text { Flexural strength under } \\
\text { concentrated load after } \\
\text { freeze - thaw cycles } \\
(\mathrm{MPa})(13)\end{array}$} & $11.3 \pm 3.2$ & $5.7 \pm 1.5$ & $5.1 \pm 0.8$ & $5.7 \pm 0.1$ & $4.9 \pm 1.3$ & $6.1 \pm 0.8$ \\
\hline
\end{tabular}

Los parámetros hídricos que presentan los granitos y las calizas son característicos de rocas poco porosas como puede verse en la Tabla 4, donde se observa que ambas rocas tienen unos coeficientes de absorción de agua similares. El comportamiento hídrico de las rocas está fuertemente condicionado por las características texturales y estructurales. El transporte del agua en las calizas se produce principalmente por la porosidad secundaria (vénulas y estilolitos) $(6,18)$ y por la porosidad primaria (porosidad intercristalina), mientras que en los granitos se produce principalmente a través de las microfisuras de tipo inter y transgranular (19).

Las microfisuras del granito Blanco Rafaela pueden observarse en las imágenes obtenidas con el microscopio de fluorescencia (Fig. 4). La concentración de estas microfisuras crea zonas más susceptibles a los procesos de envejecimiento (19-21).
Water absorption and evaporation in the granite and limestone studied were characteristic of low porosity stones, as inferred by the data in Table 4, which shows that the two stones have similar water absorption coefficients. Stone absorption is highly conditioned by texture and structural characteristics. In limestone, secondary (veins and stylolites) $(6,18)$ and primary (inter-crystalline) porosity is mainly responsible for water transport, whereas water penetrates granite through inter- and trans-granular microfissures (19).

Indeed, the microscopic images reveal microfissures in Blanco Rafaela granite (Figure 4). Where such microfissures cluster, the stone is more prone to deterioration (19-21). 
El coeficiente de absorción de agua de la caliza Gris Pulpis es menor que el de otras calizas comercializadas de zonas próximas como la Piedra de Borriol, lo cual se explica por tener la Piedra de Borriol un mayor carácter bioclástico que el Gris Pulpis (18).

El tipo de acabado ejerce una influencia pequeña en el comportamiento hídrico. Las curvas de absorción capilar son muy similares en el caso de los granitos (Figura 5A), lo que muestra que las propiedades del sistema poroso en la superficie ( $y$ de mojabilidad) no han cambiado considerablemente por el acabado; este resultado concuerda
Gris Pulpis limestone has a lower water absorption coefficient than other types of limestone such as Borriol stone, possibly because the latter is more bioclastic (18).

This type of finish has little impact on water sorption. All the capillary curves found for the granite specimens were very similar. This finding, which infers that the various types of finish do not substantially alter the surface pore system, concurs with data reported for other granites such as Rosa Porriño, Rosavel and Blanco Alcazar (15).

Tabla 4 / Table 4

Parámetros hídricos del granito Blanco Rafaela y la caliza Gris Pulpis.

Hydric parameters of the Blanco Rafaela granite and Gris Pulpis limestone.

\begin{tabular}{|l|c|c|}
\cline { 2 - 3 } \multicolumn{1}{c|}{} & \multicolumn{1}{c|}{$\begin{array}{c}\text { Gris Pulpis } \\
\text { Limestone }\end{array}$} & $\begin{array}{c}\text { Blanco Rafaela } \\
\text { Granite }\end{array}$ \\
\hline $\begin{array}{l}\text { Absorción de agua a presión atmosférica } \\
\text { Water absorption under atmospheric pressure } \\
(16)(\%):\end{array}$ & $0.66 \pm 0.15$ & $0.69 \pm 0.07$ \\
\hline $\begin{array}{l}\text { Densidad aparente, densidad real y porosidad abierta y total } \\
\text { Apparent density, real density and open and total porosity }(8)\end{array}$ & $2650 \pm 20$ & $2630 \pm 20$ \\
\hline $\begin{array}{l}\text { Densidad aparente } \\
\text { Apparent density }\left(\mathrm{Kg} / \mathrm{m}^{3}\right)\end{array}$ & $2630 \pm 10$ & $2690 \pm 10$ \\
\hline $\begin{array}{l}\text { Densidad real } \\
\text { Real density }\left(\mathrm{Kg} / \mathrm{m}^{3}\right)\end{array}$ & $1.6 \pm 0.2$ & $1.7 \pm 0.2$ \\
\hline $\begin{array}{l}\text { Porosidad abierta } \\
\text { Open porosity }(\%)\end{array}$ & $2.2 \pm 0.1$ & $2.6 \pm 0.3$ \\
\hline $\begin{array}{l}\text { Porosidad total } \\
\text { Total porosity }(\%)\end{array}$ & & \multicolumn{1}{c|}{} \\
\hline
\end{tabular}

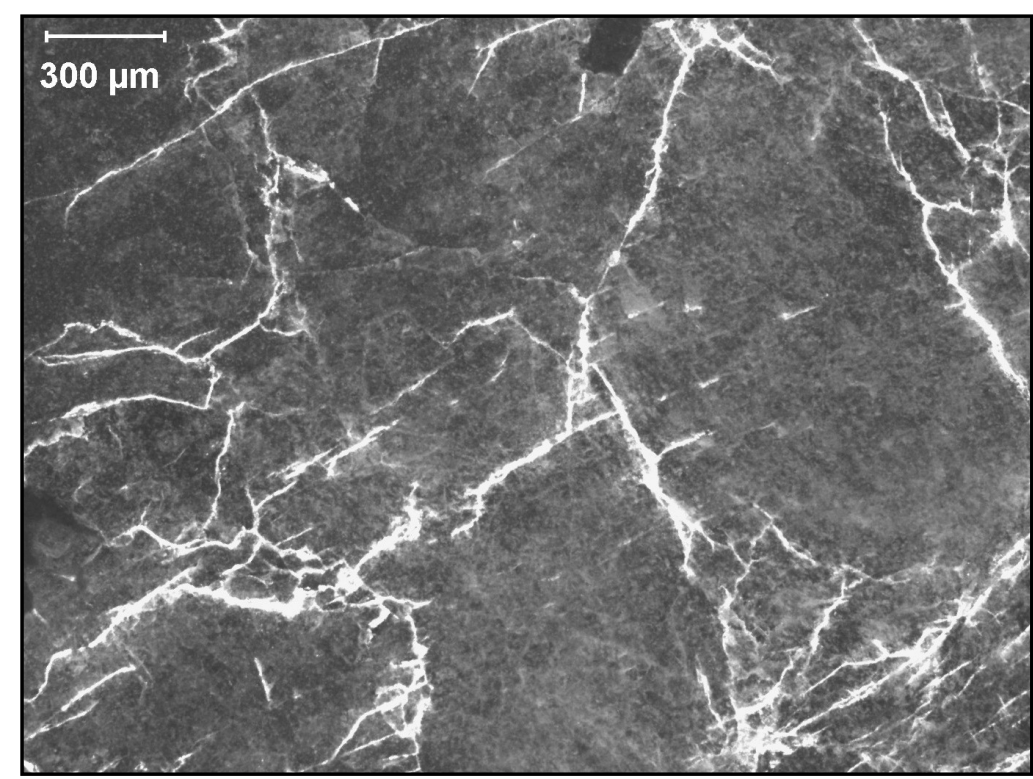

Figura 4. Microfotografía obtenida con microscopio de fluorescencia donde se observa la microfisuración del granito Blanco Rafaela.

Figure 4. Fluorescence microscope photomicrograph showing the microfissures of Blanco Rafaela granite. 


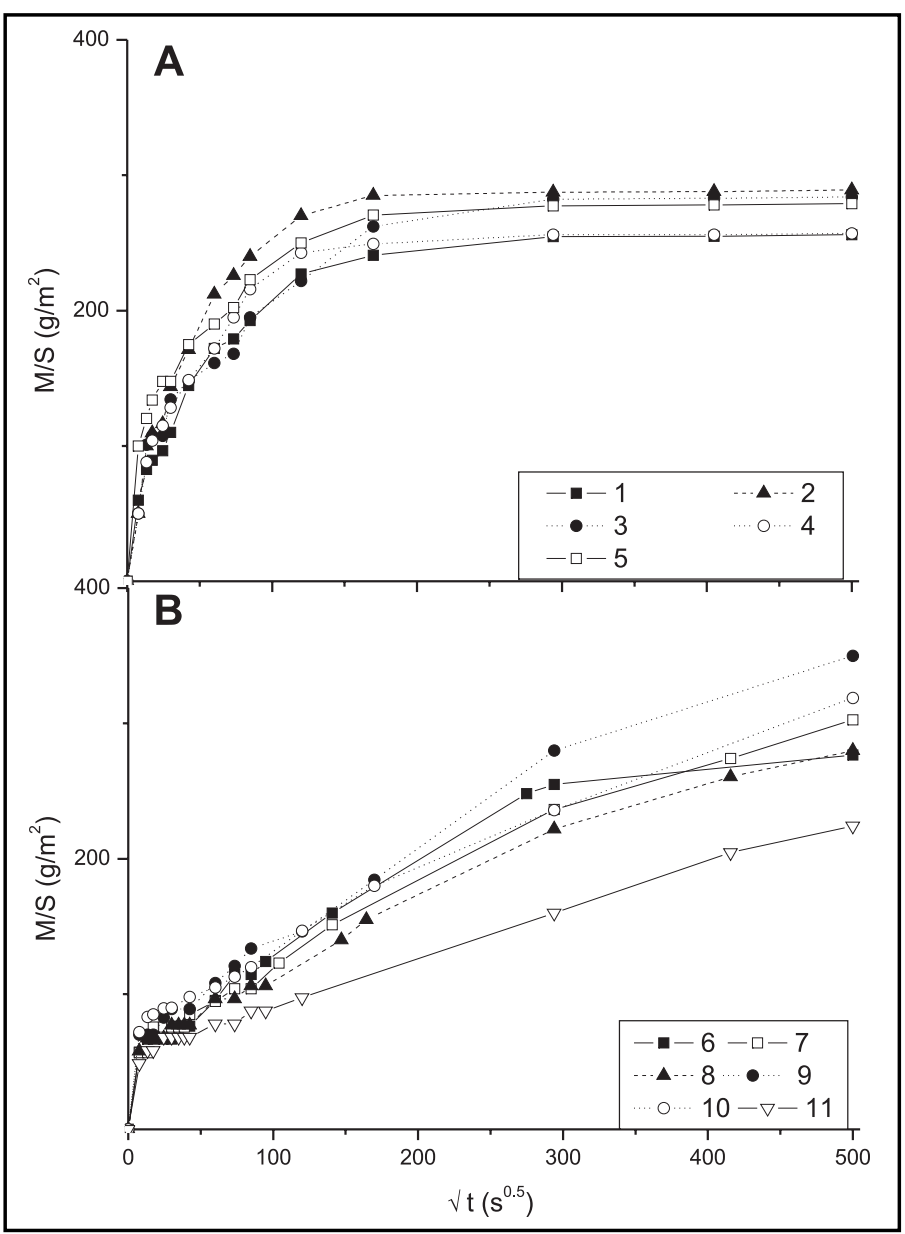

Figura 5. Curvas de capilaridad. A) Granito Blanco Rafaela: 1 pulido, 2 apomazado, 3 cara sierra, 4 abujardado, 5 flameado.

B) Caliza Gris Pulpis: 6 pulida, 7 al ácido, 8 apomazada, 9 amolada, 10 abujardada, 11 flameada.

Figure 5. Capillary absorption curves. A) Blanco Rafaela Granite; 1 polished, 2 honed, 3 sawn, 4 hammered, 5 flamed.

B) Gris Pulpis limestone; 6 polished, 7 acid treated, 8 honed, 9 abrasion treated, 10 hammered, 11 flamed.

con los obtenidos en otros granitos como Rosa Porriño, Rosavel y Blanco Alcázar (15). En los granitos el acabado pulido y abujardado son los que presentan una menor absorción (Figura $5 \mathrm{~A}$ ) y el flameado el que tiene una mayor velocidad de secado (Figura 6A).

En la caliza estudiada las curvas de capilaridad (Figura 5B) y desorción de agua (Figura 6B) muestran como los diferentes acabados tienen un comportamiento ligeramente diferente destacando el acabado flameado cuya absorción de agua es menor, posiblemente debido a la oclusión superficial de la porosidad producida por las partículas neoformadas por fusión como puede observarse en la Figura $3 \mathrm{~A}$.

\section{CONCLUSIONES}

Los granitos y las calizas microcristalinas son materiales aptos para baldosas de pavimentos exteriores, siempre que se utilice un grosor adecuado en función de su resistencia a la flexión.
Lower absorption rates were found for polished and hammered granite (Figure 5A), while the flamed specimens dried fastest (Figure 6A).

The capillary (Figure 5B) and evaporation (Figure 6B) curves for limestone varied slightly for the different finishes. The flamed finish exhibited a lower water absorption rate, for instance, very likely due to surface pore occlusion by the new particles forming as a result of the melting process (see Figure $3 A$ ).

\section{CONCLUSIONS}

Granite and micrycrystalline limestone are suitable for use as outdoor pavers, providing they are cut thick enough to ensure suitable flexural strength. 


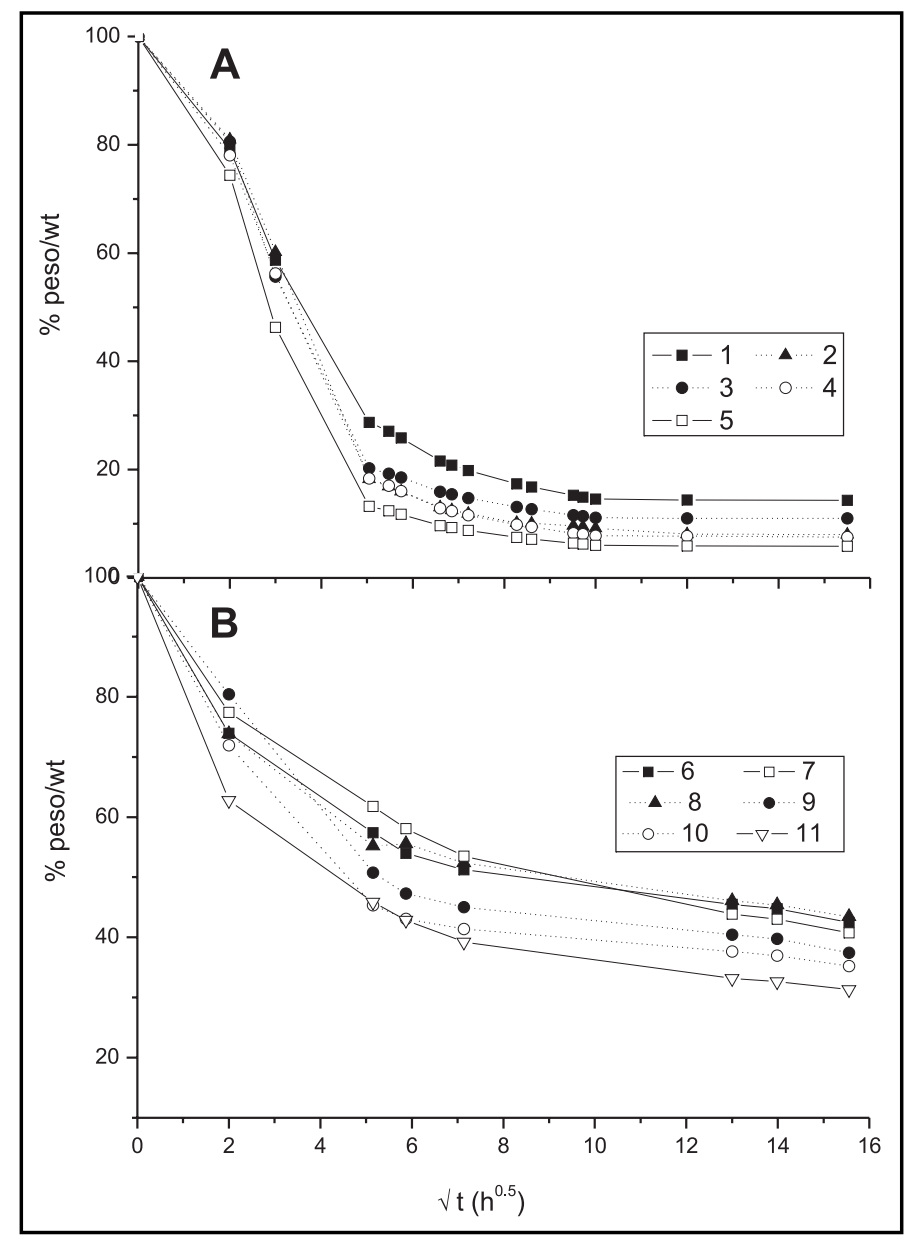

Figura 6. Curvas de desorción. A) Granito Blanco Rafaela: 1 pulido, 2 apomazado, 3 cara sierra, 4 abujardado, 5 flameado.

B) Caliza Gris Pulpis: 6 pulida, 7 al ácido, 8 apomazada, 9 amolada, 10 abujardada, 11 flameada.

Figure 6. Evaporation curves. A) Blanco Rafaela Granite; 1 polish, 2 honed, 3 sawn, 4 hammered, 5 flamed.

B) Gris Pulpis limestone; 6 polished, 7 acid treated, 8 honed, 9 abrasion, 10 hammered, 11 flamed.

El acabado debe presentar una suficiente resistencia al deslizamiento y al desgaste en función de los requerimientos necesarios para las prestaciones que debe realizar (tráfico peatonal, tráfico rodado de baja o alta intensidad, situación en llano o en rampa...). Los acabados pulidos no deben utilizarse por sus bajos valores de resistencia al deslizamiento. El acabado abujardado, en ambas rocas, es el más apto para la utilización propuesta, así como el acabado flameado en granitos. En calizas los acabados flameado y amolado presentan buenos valores de resistencia al deslizamiento, pero hay que tener en cuenta que el acabado flameado hace disminuir la resistencia a flexión de la roca por lo que se precisan grosores mayores de baldosa para obtener resultados satisfactorios.

Este trabajo forma parte del Proyecto "Evaluación de la durabilidad de la Piedra Natural utilizada en pavimentos de exteriores" subvencionado por Ministerio de Fomento y del Proyecto MATERNAS (S0505-MAT/000094) de la Comunidad de Madrid.
The finish chosen for pavers should provide sufficient slip and abrasion resistance for the intended use - pedestrian, light or heavy vehicle traffic - and position - flat or sloped. Polished finishes are inappropriate due to the low slip resistance afforded. Hammering was found to be the most suitable finish in both stones, along with flaming for granite. Both flamed and abrasion finishes provided good slip performance in limestone. Since flaming reduced

stone flexural strength, however, thicker slabs were required to ensure satisfactory performance.

This study was financed by the Spanish Ministry of Public Works and the Region of Madrid (MATERNAS Project S0505-MAT/000094) 


\section{BIBLIOGRAFÍA / BIBLIOGRAPHY}

(1) Anon: "La piedra natural de España". Anuario RocMaquina, (2007), p. 544. RocMaquina. Bilbao.

(2) UNE-EN 1341: 2002: "Baldosas de piedra natural para uso como pavimento exterior. Requisitos y métodos de ensayo: Anexo C: Determinación de la resistencia al desgaste. Anexo D: Determinación de la resistencia al deslizamiento". AENOR. Madrid. p. 38. (2002).

(3) UNE-EN 12372: 1999: Métodos de ensayo para piedra natural. Resistencia a flexión bajo carga concentrada AENOR. Madrid. p. 15, (1999).

(4) Menduiña, J., Fort, R., García-del-Cura, M. A., Galán de Frutos, L. Pérez-Soba, C. Pérez Monserrat, E. Bernabéu, A., Varas, M. J. "Las piedras utilizadas en la construcción de los bienes de interés cultural de la Comunidad de Madrid anteriores al siglo XIX". p. 133, IGME, Madrid, (2005).

(5) Villaseca, J. L.: "Sobre el origen del batolito granítico del Sistema Central español". Bol. Real Soc. Española. Hist. Nat. (2003) 98: 23-39.

(6) García-del-Cura, M.A., Benavente, D. Bernabéu, A.. Fort, R. La Iglesia, A. Ordóñez, S.: "Microcrystalline limestone used as building stone: The Case of Gris Pulpis Stone". Mater. Construcc. 55, 27, (2005), pp 5-23.

(7) Benavente, D., Martínez-Verdú, F., Bernabéu, A., Viqueira, V., Fort, R., García-del-Cura, M. A., Illueca, C., Ordóñez, S.: "Influence of Surface Roughness on Color Changes in Building Stones". Colour Research and Application. 28/ 5: (2003), pp 343-351.

(8) UNE-EN 1936: 1999: "Métodos de ensayo para piedra natural. Determinación de la densidad real y aparente y de la porosidad abierta y total". AENOR. Madrid. p. 11, (1999).

(9) UNE-EN 14579: 2005. "Métodos de ensayo para piedra natural. Determinación de la velocidad de propagación del sonido". AENOR. Madrid. $15 \mathrm{p}$.

(10) Schön, J.H.: "Physical properties of rocks: fundamentals and principles of petrophysics. Handbook of geophysical exploration". Section I, Seismic Exploration Vol. 18. Pergamon, New York, p. 583. (1996).

(11) Martínez-Martínez, J., Benavente, D., Ordóñez, S., García-del-Cura, M.A.: "Multivariate statistical techniques for evaluating the effects of brecciated rock fabric on ultrasonic waves propagation. International Journal of Rock Mechanics and Mining Sciences. (2007) In press.

(12) Bernabéu, A. "Utilización de rocas como pavimentos". En: García del Cura, M.A., y Cañaveras J.C. (eds). Seminarios de la Sociedad Española de Mineralogía, Vol. 2: Utilización de Rocas y Minerales Industriales, (2005), pp. 247 - 266.

(13) UNE-EN 1925: 1999: "Métodos de ensayo de piedra natural. Determinación del coeficiente de absorción de agua por capilaridad". AENOR Madrid. p. 13. (1999).

(14) UNE-EN 12371: 2002: "Métodos de ensayo para piedra natural. Determinación de la resistencia a la heladicidad. Ensayo tecnológico". AENOR. Madrid. p.16. (2002).

(15) Rojo, A., Alonso, F.J. Esbert, R.: "Hydric properties of some iberian ornamental granites with different superficial finishes: a petrophysical interpretation". Mater. Construcc. 53, 269, (2003), pp. 61-72.

(16) UNE-EN 13755: 2002: "Métodos de ensayo de piedra natural. Determinación de la absorción de agua a presión atmosférica". AENOR Madrid. p. 10. (2002).

(17) López, G., Mesones, F., Escribano Villan, J., Nieves Aguirre, G. "Manual para el uso de la piedra en la arquitectura". Informstone. Bilbao. p. 400. (2001).

(18) Ovejero, M., Queralt, I., de la Fuente, C.: "Petrography and hydric characterization of the quarry material of the varieties of Borriol Stone (Castellon)". Mater. Construcc. 55, 278, (2005), pp. 41-54.

(19) Sousa, L. M. O., Suarez del Rio, L. M., Calleja, L. Ruiz de Argandoña, V. G. Rodríguez Rey, A: "Influence of microfractures and porosity on the physico-mechanical properties and weathering of ornamental granites": Eng. Geology, Vol. 77, (2005), pp. 153-68.

(20) Esbert Alemany, R. "Alteration of granite stone used in building construction". Mater. Construcc. 57, 288, (2007), pp. 77-89.

(21) Alonso, F. J., Vázquez, P., Esbert, R., Ordaz, J.: Ornamental granite durability: evaluation of damage caused by salt crystalization. Mater. Construcc. 58, 289-290, (2008), In litt. On line 21-12-2007. 